\title{
Selection of common bean genotypes for the Cerrado/Pantanal ecotone via mixed models and multivariate analysis
}

\author{
A.M. Corrêa ${ }^{1}$, M.I.S. Pereira ${ }^{1}$, H.K.A. de Abreu ${ }^{2}$, T. Sharon ${ }^{1}$, \\ C.L.P. de $\mathrm{Melo}^{3}$, M.A. Ito ${ }^{4}$, P.E. Teodoro ${ }^{5}$ and L.L. Bhering ${ }^{5}$ \\ ${ }^{1}$ Departamento de Fitotecnia, \\ Universidade Estadual do Mato Grosso do Sul, Aquidauana, MS, Brasil \\ ${ }^{2}$ Departamento de Fitotecnia, \\ Universidade Federal da Grande Dourados, Dourados, MS, Brasil \\ ${ }^{3}$ Embrapa Soja, Londrina, PR, Brasil \\ ${ }^{4}$ Embrapa Agropecuária Oeste, Dourados, MS, Brasil \\ ${ }^{5}$ Laboratório de Biometria, Departamento de Biologia Geral, \\ Universidade Federal de Viçosa, Viçosa, MG, Brasil \\ Corresponding author: P.E. Teodoro \\ E-mail: eduteodoro@hotmail.com
}

Genet. Mol. Res. 15 (4): gmr15048888

Received June 16, 2016

Accepted August 1, 2016

Published October 17, 2016

DOI http://dx.doi.org/10.4238/gmr15048888

Copyright (C) 2016 The Authors. This is an open-access article distributed under the terms of the Creative Commons Attribution ShareAlike (CC BY-SA) 4.0 License.

\begin{abstract}
The common bean, Phaseolus vulgaris, is predominantly grown on small farms and lacks accurate genotype recommendations for specific micro-regions in Brazil. This contributes to a low national average yield. The aim of this study was to use the methods of the harmonic mean of the relative performance of genetic values (HMRPGV) and the centroid, for selecting common bean genotypes with high yield, adaptability, and stability for the Cerrado/Pantanal ecotone region in Brazil. We evaluated 11 common bean genotypes in three trials
\end{abstract}


carried out in the dry season in Aquidauana in 2013, 2014, and 2015. A likelihood ratio test detected a significant interaction between genotype $\mathrm{x}$ year, contributing $54 \%$ to the total phenotypic variation in grain yield. The three genotypes selected by the joint analysis of genotypic values in all years (Carioca Precoce, BRS Notável, and CNFC 15875) were the same as those recommended by the HMRPGV method. Using the centroid method, genotypes BRS Notável and CNFC 15875 were considered ideal genotypes based on their high stability to unfavorable environments and high responsiveness to environmental improvement. We identified a high association between the methods of adaptability and stability used in this study. However, the use of centroid method provided a more accurate and precise recommendation of the behavior of the evaluated genotypes.

Key words: Phaseolus vulgaris; Centroid method; HMRPGV method

\section{INTRODUCTION}

Currently, Brazil is the largest producer of common bean (Phaseolus vulgaris L.), with an estimated production of 2.9 million tons in 2014 (Fao - Food and Agriculture Organization of United Nations, 2015). However, the average yield of $1.0 \mathrm{t} / \mathrm{ha}$ (Conab - Companhia Nacional de Abastecimento, 2015) obtained from this crop can be considered low, given that the productive potential can reach $4.5 \mathrm{t} / \mathrm{ha}$ (Silva et al., 2015). Several factors are attributed to this low productivity, for example the predominant cultivation on small farms and the lack of accurate genotype recommendations for specific micro-regions (Martins et al., 2016). Thus, the selection of genotypes with high productivity, adaptability, and stability with respect to the soil and climatic conditions in a particular location is a way to increase the national average yield over the medium term.

Common bean is grown in the Cerrado/Pantanal ecotone region on small farms that do not have reliable recommendations of the genotypes adapted to their particular soil and climate conditions. This region has unique climatic attributes owing to its location in the transition zone between two national biomes: Cerrado and Pantanal (Teodoro et al., 2016). The agronomic performance of common bean genotypes in this region has been assessed by Corrêa et al. (2015) and their results demonstrated that it is possible to exceed the current national average. However, studies are needed to investigate the temporal integration between genotypes $\mathrm{x}$ years, to evaluate the performance of genotypes over time.

A genotype $x$ environment (GxE) interaction can be defined as the differential expression of genes in response to environmental variation. In the case of a genotype $\mathrm{x}$ year (time) interaction, the best genotype in one year may not be the best in subsequent years. Genotype $\mathrm{x}$ year interactions may occur owing to two factors: variability differences between genotypes over time and inconsistency of the superiority of genotypes to environmental variation (Cruz et al., 2012). The second factor complicates the recommendation of genotypes with high stability and productivity for a given region, as there may be genotypes with superior performance in a given year, but not in other years.

In recent years, new approaches have been employed for quantifying GxE interactions, for example pattern analysis (Corrêa et al., 2016a), Bayesian statistics (Corrêa et al., 2016b),

Genetics and Molecular Research 15 (4): gmr15048888 
and computational intelligence (Corrêa et al., 2016c). However, one of the conditions for the use of these approaches is availability of data from a large number of environments (locations and/or times). Among the analyses available for a limited number of environments, the centroid method (Rocha et al., 2005) uses a principal component multivariate technique to compare the performance of genotypes with landmarks of maximum adaptability and stability, helping the breeder to identify general or specific adaptability genotypes.

The method of harmonic mean of the relative performance of the genetic values (HMRPGV) based on the use of mixed models, can also be applied effectively to a reduced number of environments (Resende, 2007). This method provides adaptability and genotypic stability estimates, whose genetic values are penalized by instability. This method has been used for interpretation of genotypic stability and adaptability of crops such as common bean (Carbonell et al., 2007), rice (Regitano Neto et al., 2013), and cowpea (Torres et al., 2015, 2016). The aim of this study was to use the HMRPGV and centroid methods for selecting common bean genotypes with high yield, adaptability, and stability specific to the Cerrado/ Pantanal ecotone region.

\section{MATERIAL AND METHODS}

The experiments were conducted in the experimental area of Universidade Estadual de Mato Grosso do $\mathrm{Sul}\left(20^{\circ} 20^{\prime} \mathrm{S}, 55^{\circ} 48^{\prime} \mathrm{W}\right.$ and $207 \mathrm{~m}$ in altitude), municipality of Aquidauana, located in the transition region between Cerrado and Pantanal biomes. Three experiments were performed in the dry season with sowings occurring between April 25 and 30 in 2013, 2014, and 2015. Each year, we performed conventional tillage and, at sowing, we applied 200 $\mathrm{kg} / \mathrm{ha}$ of a commercial base fertilizer (formula 4-20-20). Topdressing was added at the V4 stage employing $50 \mathrm{~kg} / \mathrm{ha} \mathrm{N}$ as urea alongside the rows of plants.

We assessed 11 common bean genotypes (BRS Notável, Carioca Precoce, IPR Colibri, CNFC 15502, CNFC 15625, CNFC 15626, CNFC 15629, CNFC 15630, CNFC 15873, CNFC 15874, and CNFC 15875) in a randomized block design with three replications. The experimental units consisted of four lines of plants that were $1.50 \mathrm{~m}$ long and spaced $0.50 \mathrm{~m}$ apart. Grain yield expressed in $\mathrm{kg} / \mathrm{ha}$ was evaluated in the central rows, taking into account the harvested area and adjusting the data to $13 \%$ moisture.

Initially, each year was classified as favorable or unfavorable according to the environmental index proposed by Finlay and Wilkinson (1963):

$$
\mathrm{Ij}=\frac{1}{\mathrm{~g}} \sum_{\mathrm{i}} \mathrm{Y}_{\mathrm{ij}}-\frac{1}{\mathrm{ng}} \mathrm{Y} . .
$$

where in $\mathrm{Y}_{\mathrm{ij}}$ is the mean of the genotype $\mathrm{i}$ in the year $\mathrm{j}$; $\mathrm{Y}$.. is the total number of observations; $\mathrm{n}$ is the number of years; and $\mathrm{g}$ is the number of genotypes. If $\mathrm{Ij}$ is positive, the year is favorable and if $\mathrm{Ij}$ is negative, the year is considered unfavorable.

To assess the effect of the GxE interaction, we used the following statistical model:

$$
\mathrm{y}=\mathrm{Xm}+\mathrm{Zg}+\mathrm{Wp}+\mathrm{Ti}+\mathrm{e}
$$

(Equation 2)

where in $y$ is the vector of observations; $m$ is the vector of the effects of year-repeat combinations

Genetics and Molecular Research 15 (4): gmr15048888 
(fixed) added to the overall average with $m \sim \mathrm{N}(X m, \mathrm{~V}) ; g$ is the vector of phenotypic effects (random) with $g \sim \mathrm{N}\left(0, \mathrm{I} \hat{\sigma}_{\mathrm{g}}^{2}\right) ; p$ is vector of the permanent environmental effects (plots in case) (random) with $p \sim \mathrm{N}\left(0, \mathrm{I}_{\mathrm{p}}^{2}\right) ; i$ is the vector of the effects of the genotype $\mathrm{x}$ year interactions (random) with $i \sim \mathrm{N}\left(0, \mathrm{I}_{\mathrm{g}_{\mathrm{gx}}}^{2}\right)$; and $e$ is the vector of residual errors (random) with $e \sim \mathrm{N}(0, \mathrm{I}$ $\left.\hat{\sigma}_{\mathrm{e}}^{2}\right)$. Capital letters $X, Z, W$, and $T$ represent the respective incidence matrices for these factors. For the analysis of random effects we used, the likelihood ratio test (LRT), performed based on the difference between the model deviances with and without the effect to be tested. The significance test of these models was performed using a chi-square test with 1 degree of freedom.

Using this model, we obtained genotypic values $(\mathrm{GV})$ for each years (with the interaction effect) using Equation 3 and GV capitalizing the average interaction in the different environments (Equation 4):

$$
\begin{gathered}
\mathrm{GV}=\hat{\mu}_{\mathrm{j}}+\hat{\mathrm{g}}_{\mathrm{ij}}+(\hat{\mathrm{ge}})_{i} \\
\mathrm{GV}=\hat{\mu}_{\mathrm{j}}+\hat{\mathrm{g}}_{\mathrm{i}}+\hat{\mathrm{ge}}_{\mathrm{m}}
\end{gathered}
$$

where in $\hat{\mu}_{\mathrm{j}}$ is the mean of the year $\mathrm{j}$; $\hat{\mathrm{g}}_{\mathrm{j}}$ is the genotypic effect of the genotype $\mathrm{i}$ in year $\mathrm{j}$; $(\hat{\mathrm{ge}})_{\mathrm{i}}$ is the effect of the GxE interaction for genotype $\mathrm{i}$; and $\mathrm{ge}_{\mathrm{m}}$ is the average GxE interaction in different years.

To evaluate stability and adaptability, the harmonic mean values of the GV (HMGV) and the relative performance of the GV (RPGV), respectively, were used, whereas the HMRPGV method was used for simultaneous selection for grain yield, stability, and adaptability. These were obtained using equations 5,6 , and 7 , respectively:

$$
\begin{aligned}
\mathrm{HMGV}_{\mathrm{i}} & =\frac{\mathrm{n}}{\sum_{\mathrm{j}=1}^{\mathrm{n}} \frac{1}{G V_{i j}}} \\
\mathrm{RPGV}_{\mathrm{i}} & =\frac{1}{\mathrm{n}} \frac{\sum_{\mathrm{j}=1}^{\mathrm{n}} \mathrm{GV}_{\mathrm{ij}}}{\mathrm{M}_{\mathrm{j}}} \\
\mathrm{HMRPGV}_{\mathrm{i}} & =\frac{\mathrm{n}}{\sum_{\mathrm{j}=1}^{\mathrm{n}} \frac{1}{\mathrm{RPGV}_{\mathrm{ij}}}}
\end{aligned}
$$

where $\mathrm{n}$ is the number of years $(\mathrm{N}=3)$ for the evaluated genotype $\mathrm{i}, \mathrm{GV}_{\mathrm{ij}}$ is the $\mathrm{GV}$ of genotype $i$ in year $j$, expressed as a mean proportion of this environment; $M_{j}$ is the average grain yield in year $\mathrm{j}$. The analyses were performed using the Selegen software (Resende, 2007).

Genetics and Molecular Research 15 (4): gmr15048888 
Subsequently, the predicted values were subjected to the genotypic centroid method proposed by Rocha et al. (2005) using Genes software (Cruz, 2013). This method is based on the comparison of Cartesian distance values between the genotypes and references that are considered ideal (ideotypes). Thus, using the bissegmented regression model developed by Cruz et al. (1989), the following four reference ideotypes of interest were defined for this study: Ideotype 1 has a mean higher than the overall mean of the common bean genotypes in all three years, low response to unfavorable environments $\left(\hat{\beta}_{1}<1.0\right)$, and is responsive in favorable environments $\left(\hat{\beta}_{1}+\hat{\beta}_{2}>1.0\right)$. Ideotype 2 has a mean higher than the overall mean of genotypes of the evaluated common bean genotypes in all three years and overall adaptability $\left(\hat{\beta}_{1}=1.0\right.$ and $\hat{\beta}_{2}=0$ ). Ideotype 3 has a mean higher than the overall mean of the common bean genotypes in all three years, is responsive to environmental improvement $\left(\hat{\beta}_{1}+\hat{\beta}_{2}>1.0\right)$, but is sensitive to unfavorable environments $\left(\hat{\beta}_{1}>1.0\right)$. Finally, ideotype 4 has a mean higher than the overall mean of the common bean genotypes in all three years, does not respond to environmental improvement $\left(\hat{\beta}_{1}+\hat{\beta}_{2}<1.0\right)$, but shows yield stability to unfavorable environments $\left(\hat{\beta}_{1}<1.0\right)$.

After classifying the years and identifying representative reference points of ideotypes (centroids), we used a principal component analysis (PCA) considering the average matrix of dimension $11 \times 3$ and four lines corresponding to the established ideotypes. From the PCA of the 11 genotypes (including the four ideotypes), we obtained scores used for the graphical representation. The position of each genotype in relation to the centroids in the graphic and the values of the Cartesian distance between the points (genotypes) and each centroid enable the classification of each genotype in terms of adaptability and stability (Rocha et al., 2005).

\section{RESULTS AND DISCUSSION}

The LRT was significant $(\mathrm{P}<0.01)$ for genotype, year, and for the GxE interaction (Table 1). The genotype x year variance $\left(\hat{\sigma}_{\mathrm{gxy}}^{2}\right)$ can inflate the phenotypic expression of a trait owing to the greater or lesser degree of genetic adaptability/stability of individuals (Torres et al., 2015). The magnitude of $\hat{\sigma}_{\mathrm{gxy}}^{2}$ indicated that the genotype $\mathrm{x}$ year interaction contributed $54 \%$ of the total phenotypic variation. Therefore, a genotype with good productivity in one year does not maintain the same level across all years, showing low predictability with respect to the environmental variation.

Table 1. Deviance, likelihood ratio test (LRT), variance components, and coefficients of determination for grain yield evaluated in 11 common bean genotypes evaluated in three years in the Cerrado/Pantanal ecotone.

\begin{tabular}{l|c|c|c|c}
\hline Effect & Deviance & LRT $\left(\chi^{2}\right)$ & Variance component & Coefficient of determination \\
\hline Genotype & $1130.32^{+}$ & $9.99^{*}$ & $\hat{\sigma}_{\mathrm{g}}^{2}=9730.64$ & $\hat{\mathrm{h}}_{\mathrm{g}}^{2}=0.10$ \\
\hline Year & $1130.46^{+}$ & $10.13^{*}$ & $\hat{\sigma}_{\mathrm{y}}^{2}=11676.76$ & $\mathrm{c}_{\mathrm{y}}^{2}=0.12$ \\
\hline Genotype x Year & $1142.22^{+}$ & $21.89^{*}$ & $\hat{\sigma}_{\mathrm{gxy}}^{2}=52545.44$ & $\mathrm{c}_{\mathrm{gxy}}^{2}=0.54$ \\
\hline Residual & - & - & $\hat{\sigma}_{\mathrm{e}}^{2}=25299.66$ & $\mathrm{c}_{\mathrm{e}}^{2}=0.26$ \\
\hline Full model & 1120.33 & - & $\mathrm{c}_{\text {total }}^{2}=1.00$ \\
\hline
\end{tabular}

${ }^{+}$: Model deviance adjusted without the corresponding effect. *Significant at $1 \%$ probability based on a chi-square test. $\hat{\sigma}_{\mathrm{g}}^{2}$ : genotipic variance; $\hat{\sigma}_{\mathrm{c}}^{2}$ : temporal variance; $\hat{\sigma}_{\mathrm{gxy}}^{2}$ : genotype x year variance; $\hat{\sigma}_{\mathrm{e}}^{2}$ : residual variance; $\hat{\mathrm{h}}_{\mathrm{g}}^{2}$ : heritability of genotypes; $\mathrm{c}_{\mathrm{y}}^{2}$ : temporal coefficient of determination; $\mathrm{c}_{\mathrm{gxy}}^{2}$ : genotype $\mathrm{x}$ year interaction coefficient of determination; $\mathrm{c}_{\mathrm{e}}^{2}$ : residual coefficient of determination.

Genetics and Molecular Research 15 (4): gmr15048888 
The occurrence of a significant temporal interaction may be attributed to unpredictable effects of temperature and rainfall that occurred in each year (Table 2). For instance, it is worth noting that in the years 2013 and 2014, both of which were classified as favorable, a cumulative rainfall greater than $300 \mathrm{~mm}$ was observed over the trial period. In the experiment conducted in 2015 , the cumulative total rainfall was only $228 \mathrm{~mm}$, which potentially contributed to the classification of this year as unfavorable. Thus, the genotype differential behavior in response to temporal variation indicates that adaptability and stability analyses are necessary for safer recommendation of common bean genotypes for the Cerrado/Pantanal ecotone region.

Table 2. Weather conditions, environmental indices (Ij), and rating of each trial year.

\begin{tabular}{l|c|c|c|c|c|l}
\hline Year & Average temperature $\left({ }^{\circ} \mathrm{C}\right)$ & Maximum temperature $\left({ }^{\circ} \mathrm{C}\right)$ & Minimum temperature $\left({ }^{\circ} \mathrm{C}\right)$ & Accumulated rainfall $(\mathrm{mm})$ & \multicolumn{1}{c}{$\mathrm{Ij}$} & Rating \\
\hline 2013 & 25.76 & 33.07 & 20.04 & 312.00 & 62.40 & Favorable \\
\hline 2014 & 26.04 & 34.15 & 19.43 & 316.60 & 186.41 & Favorable \\
\hline 2015 & 25.90 & 33.61 & 19.73 & 228.60 & -248.81 & Unfavorable \\
\hline
\end{tabular}

For each year and in the combined analysis of all years, the coefficient of environmental variation (CVe) was less than 20\% (Table 3). Cruz et al. (2012) reported that for quantitative continuously distributed traits, such as grain yield, CVe values lower that $20 \%$ denote excellent experimental accuracy. On the other hand, high coefficient of genetic variation $(\mathrm{CVg})$ values are desirable because they indicate that a large fraction of the genetic variance $\left(\hat{o}_{\mathrm{g}}^{2}\right)$ was extracted from the total phenotypic variance. Thus, it is possible that the observed $\mathrm{CVg}$ values approached the CVe values every year. However, in the combined analysis (each year), the estimated $\mathrm{CVe}$ values was twice as large as the $\mathrm{CVg}$, which indicates that the temporal interactions consumed genetic variability over time. By analyzing the predicted genotypic values for each year, we noted that there was a change in the ordering of the best genotypes depending on the assessed year. However, it is worth noting that the Carioca Precoce genotype was found to be among the best genotypes in each individual year $(2013,2014$, and 2015), as well as in the joint analysis of all years (capitalizing the average interaction with all evaluated years). The other genotypes selected in the joint analysis of all years were BRS Notável and CNFC 15875. When conducting the joint analysis of all years, the mixed model methodology considers the genotypic standard deviation of genotypes in each year, penalizing genotypes whose values are high, which provides high credibility to the procedure.

Table 3. Estimates of genotypic values, coefficient of genetic $(\mathrm{CVg})$ and environmental $(\mathrm{CVe})$ variation for grain yield evaluated in 11 common bean genotypes in the Cerrado/Pantanal ecotone.

\begin{tabular}{l|l|c|c|c|c}
\hline Identification & Genotype & 2013 & 2014 & 2015 & All years \\
\hline G1 & BRS Notável & 1322.86 & 1470.53 & $\mathbf{1 1 9 8 . 4 8}$ & $\mathbf{1 2 1 4 . 7 3}$ \\
\hline G2 & Carioca Precoce & $\mathbf{1 4 5 7 . 0 1}$ & $\mathbf{1 5 6 6 . 5 4}$ & $\mathbf{1 2 9 7 . 7 7}$ & $\mathbf{1 4 2 2 . 9 8}$ \\
\hline G3 & IPR Colibri & 1405.23 & 1492.76 & 1084.81 & 1191.89 \\
\hline G4 & CNFC 15502 & 1341.47 & 1442.16 & 995.98 & 1073.81 \\
\hline G5 & CNFC 15625 & 1360.59 & 1362.84 & $\mathbf{1 2 4 0 . 7 0}$ & 1163.39 \\
\hline G6 & CNFC 15626 & 1282.70 & 1511.07 & 961.52 & 1075.81 \\
\hline G7 & CNFC 15629 & $\mathbf{1 4 8 2 . 6 4}$ & 1418.58 & 1036.69 & 1169.59 \\
\hline G8 & CNFC 15630 & 1382.42 & 1537.61 & 842.11 & 1073.15 \\
\hline G9 & CNFC 15873 & $\mathbf{1 4 2 5 . 2 9}$ & 1393.62 & 920.47 & 1040.71 \\
\hline G10 & CNFC 15874 & 1302.68 & $\mathbf{1 6 1 6 . 6 9}$ & 878.52 & 1086.13 \\
\hline CVg $(\%)$ & CNFC 15875 & 1266.16 & $\mathbf{1 5 8 0 . 8 1}$ & 1148.73 & $\mathbf{1 2 1 5 . 1 9}$ \\
\hline CVe $(\%)$ & & 13.49 & 12.25 & 14.78 & 9.31 \\
\hline & & 15.56 & 14.44 & 16.91 & 18.97 \\
\hline
\end{tabular}

Genetics and Molecular Research 15 (4): gmr15048888 
Estimates are presented both for each of the three evaluated years and for the joint analysis of all years (capitalizing the average interaction with all evaluated years). Values in bold correspond to the three most productive genotypes for each year.

The three genotypes selected by the joint analysis for all years (Carioca Precoce, BRS Notável, and CNFC 15875) were the same as those identified using the methods that capitalized adaptability (RPGV) and adaptability and stability (HMRPGV) simultaneously (Table 4). This indicates that these genotypes showed genotypic adaptability and stability among the three years analyzed, in addition to having high yield, maintaining this trait even in the face of varying climatic conditions. Carbonell et al. (2007) employed this methodology for selection of common bean lines to regions of São Paulo. They concluded that the method adequately provides estimates of adaptability and genotypic stability, generates results of the magnitude or scale of the rated trait, facilitates the recommendation of genotypes, and can be applied to unbalanced and heterogeneous treatments (Carbonell et al., 2007).

Table 4. Stability of the genotypic values (HMGH), adaptability of genotypic values (RPGV and RPGV $\mu$ ), adaptability, and stability of genotypic values (HMRPGV and HMRPGV $\mu$ ) for grain yield evaluated in 11 common bean genotypes evaluated in three years in the Cerrado/Pantanal ecotone.

\begin{tabular}{l|l|c|c|c|c|c}
\hline Identification & Genotype & HMGV & RPGV & RPGV $\mu$ & HMRPGV & HMRPGV $\mu$ \\
\hline G1 & BRS Notável & $\mathbf{1 2 0 7 . 7 4}$ & $\mathbf{1 . 0 8}$ & $\mathbf{1 2 5 1 . 9 1}$ & $\mathbf{1 . 0 6}$ & $\mathbf{1 2 2 3 . 6 1}$ \\
\hline G2 & Carioca Precoce & $\mathbf{1 4 1 5 . 5 1}$ & $\mathbf{1 . 2 7}$ & $\mathbf{1 4 6 5 . 6 2}$ & $\mathbf{1 . 2 4}$ & $\mathbf{1 4 3 4 . 5 9}$ \\
\hline G3 & IPR Colibri & 1126.47 & 1.03 & 1185.99 & 1.02 & 1184.85 \\
\hline G4 & CNFC 15502 & 1017.08 & 0.92 & 1069.87 & 0.92 & 1068.59 \\
\hline G5 & CNFC 15625 & 1157.52 & 1.06 & 1221.87 & 1.00 & 1151.30 \\
\hline G6 & CNFC 15626 & 997.71 & 0.92 & 1063.39 & 0.91 & 1055.91 \\
\hline G7 & CNFC 15629 & 1093.43 & 1.01 & 1164.30 & 0.99 & 1149.44 \\
\hline G8 & CNFC 15630 & 843.68 & 0.88 & 1022.80 & 0.81 & 942.79 \\
\hline G9 & CNFC 15873 & 915.01 & 0.88 & 1016.82 & 0.85 & 986.72 \\
\hline G10 & CNFC 15874 & 859.35 & 0.89 & 1034.58 & 0.83 & 955.31 \\
\hline G11 & CNFC 15875 & $\mathbf{1 1 7 3 . 5 8}$ & $\mathbf{1 . 0 6}$ & $\mathbf{1 2 3 0 . 2 6}$ & $\mathbf{1 . 0 4}$ & $\mathbf{1 2 0 7 . 3 6}$ \\
\hline
\end{tabular}

Values in bold correspond to the three best genotypes selected for each statistic.

The use of different methods for investigating temporal interactions provides additional results, which can be interpreted together. The concepts of adaptability and the centroid method stability are based on performance comparisons of the genotypes with respect to reference points (the centroids), estimated from experimental data (Rocha et al., 2005). The cumulative obtained variance of the first two principal components was $80.75 \%$ (Figure 1), a value considered by Cruz et al. (2012) as suitable for data interpretation for this method.

The genotypes Carioca Precoce (G2), IPR Colibri (G3), CNFC 15502 (G4), CNFC 15629 (G7), and CNFC 15873 (G9) showed greater proximity to centroid II, which was considered to have a general average in adaptability and stability. The genotypes CNFC 15630 (G8) and CNFC 15874 (G10) can be classified as having a specific adaptability to favorable environments based on their proximity to centroid III. These genotypes can thus be recommended for producers who adopt a high technological level in terms of fertilization, cultural practices, and supplementary irrigation, as they significantly respond to environmental improvements.

On the other hand, small producers can use genotype CNFC 15625 (G5), which has a high adaptive ability to unfavorable environments (based on its location near centroid IV) and an ability to maintain its production potential even in adverse weather conditions. The genotypes BRS Notável (G1) and CNFC 15875 (G11), located near centroid I, can be 


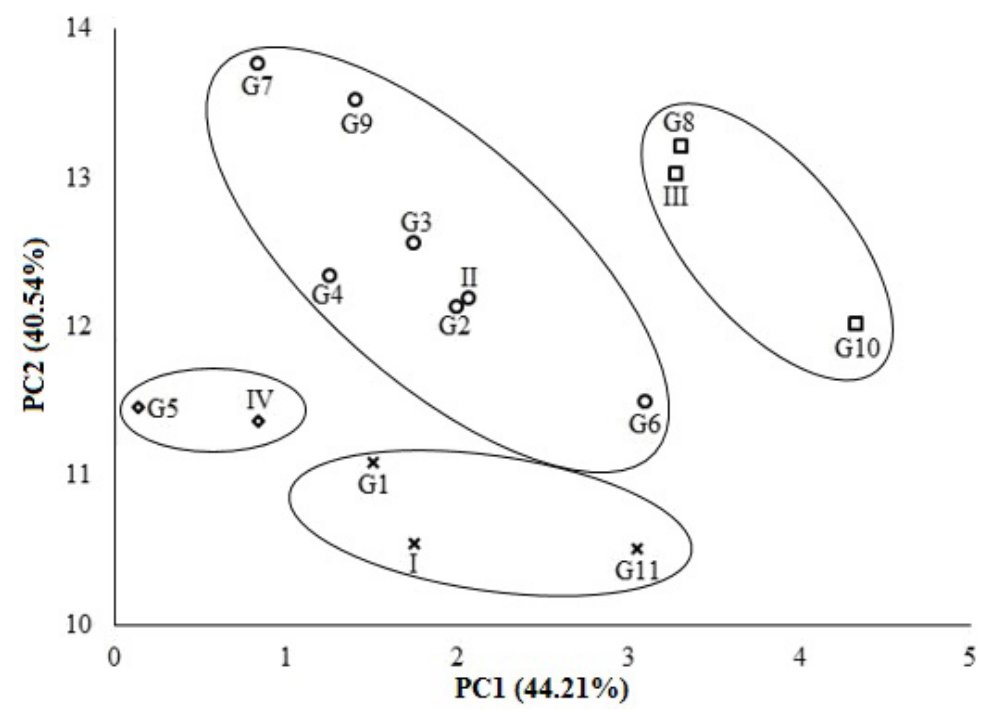

Figure 1. Graphic dispersion of the first two principal components (PC) of grain yield evaluated in 11 common bean genotypes (G1-11, corresponding to the genotypes presented in Table 3) evaluated in three years in the Cerrado/ Pantanal ecotone with four reference points (centroids) marked with roman numerals.

considered overall ideal genotypes according to Cruz et al. (2012), because they have high stability to unfavorable environments $\left(\hat{\hat{a}}_{1}<1.0\right)$ and are highly responsive to environmental improvement $\left(\hat{\hat{a}}_{1}+\hat{\hat{a}}_{2}>1.0\right)$. It is important to note that there was a high association between the adaptability and stability methods employed in this study; however, the use of the centroid method provided a more accurate and precise recommendation for the behavior of the evaluated common bean genotypes. Finally, we would like to emphasize that this is the first paper that provides a recommendation for bean genotypes aimed at farmers in the Cerrado/ Pantanal ecotone region. Based on this information, both small and large farms in the region can use the recommended genotypes, contributing to increase the average grain yield in the State of Mato Grosso do Sul in Brazil.

\section{Conflicts of interest}

The authors declare no conflict of interest.

\section{ACKNOWLEDGMENTS}

Research supported by Coordenação de Aperfeiçoamento de Pessoal de Nível Superior (CAPES) and Conselho Nacional de Desenvolvimento Científico e Tecnológico (CNPq).

\section{REFERENCES}

Carbonell SAM, Chioratto AF, Resende MDV, Dias LAS, et al. (2007). Estabilidade de cultivares e linhagens de feijoeiro em diferentes ambientes no Estado de São Paulo. Bragantia 66: 193-201. http://dx.doi.org/10.1590/S0006$\underline{87052007000200003}$

Genetics and Molecular Research 15 (4): gmr15048888 
Conab - Companhia Nacional de Abastecimento (2015). Acompanhamento da safra brasileira: Grãos 2013/2014. Décimo levantamento/Agosto 2014. Available at [http://www.conab.gov.br]. Accessed July 10, 2015.

Corrêa AM, Lima ARS, Braga DC, Ceccon G, et al. (2015). Agronomic performance and genetic variability among common bean genotypes in Savanna/Pantanal ecotone. J. Agron. 14: 175-179. http://dx.doi.org/10.3923/ja.2015.175.179

Corrêa AM, Gonçalves MC and Teodoro PE (2016a). Pattern analysis of multi-environment trials in common bean genotypes. Biosci. J. 32: 328-336. http://dx.doi.org/10.14393/BJ-v32n2a2016-29572

Corrêa AM, Teodoro PE, Gonçalves MC, Barroso LM, et al. (2016b). Adaptability and phenotypic stability of common bean genotypes through Bayesian inference. Genet. Mol. Res. 15: 10.4238/gmr.15028260.

Corrêa AM, Teodoro PE, Gonçalves MC, Barroso LM, et al. (2016c). Artificial intelligence in the selection of common bean genotypes with high phenotypic stability. Genet. Mol. Res. 15: 10.4238/gmr.15028230.

Cruz CD (2013). Genes: a software package for analysis in experimental statistics and quantitative genetics. Acta Sci. Agron. 35: 271-276.

Cruz CD, Torres RA and Vencovsky R (1989). An alternative approach to the stability analysis proposed by Silva and Barreto. Rev. Bras. Genet. 12: 567-580.

Cruz CD, Carneiro PCS and Regazzi AJ (2012). Modelos biométricos aplicados ao melhoramento genético. 3rd ed. Editora UFV, Viçosa.

Fao - Food and Agriculture Organization of United Nations (2015). Food and agricultural commodities production. Available at [http://www.fao.org]. Accessed July 10, 2015.

Finlay KW and Wilkinson GN (1963). The analysis of adaptation in a plant-breeding programme. Aust. J. Agric. Res. 14: 742-754. http://dx.doi.org/10.1071/AR9630742

Martins SM, Melo PG, Faria LC, Souza TL, et al. (2016). Genetic parameters and breeding strategies for high levels of iron and zinc in Phaseolus vulgaris L. Genet. Mol. Res. 15: http://dx.doi.org/10.4238/gmr.15028011.

Regitano Neto A, Ramos Júnior EA, Gallo PB, Freitas JG, et al. (2013). Comportamento de genótipos de arroz de terras altas no estado de São Paulo. Rev. Cienc. Agron. 44: 512-519. http://dx.doi.org/10.1590/S1806-66902013000300013

Resende MDV (2007). SELEGEN-REML/BLUP: sistema estatístico e seleção genética computadorizada via modelos lineares mistos. Embrapa Florestas, Colombo.

Rocha RB, Muro-Abad JI, Araújo EF and Cruz CD (2005). Avaliação do método centróide para estudo da estabilidade e adaptabilidade ao ambiente. Cienc. Florest. 15: 255-266. http://dx.doi.org/10.5902/198050981863

Silva MG, Arf O and Teodoro PE (2015). Nitrogen topdressing and application ways of fluazifop-p-butyl + fomesafen in weed control and agronomic performance of common bean. An. Acad. Bras. Cienc. 87: 2301-2307. http://dx.doi. org/10.1590/0001-3765201520140347

Teodoro PE, Oliveira-Júnior JF, Cunha ER, Correa CCG, et al. (2016). Cluster analysis applied to the spatial and temporal variability of monthly rainfall in Mato Grosso do Sul State, Brazil. Meteorol. Atmos. Phys. 128: 197-209. http:// dx.doi.org/10.1007/s00703-015-0408-y

Torres FE, Teodoro PE, Sagrilo E, Ceccon G, et al. (2015). Interação genótipo x ambiente em genótipos de feijão-caupi semiprostrado via modelos mistos. Bragantia 74: 255-260. http://dx.doi.org/10.1590/1678-4499.0099

Torres FE, Teodoro PE, Rodrigues EV, Santos A, et al. (2016). Simultaneous selection for cowpea (Vigna unguiculata L.) genotypes with adaptability and yield stability using mixed models. Genet. Mol. Res. 15: gmr.15028272 http:// dx.doi.org/10.4238/gmr.15028272.

Genetics and Molecular Research 15 (4): gmr15048888 